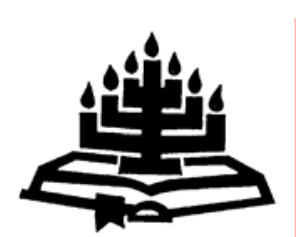

\title{
'n Teologies-etiese beoordeling van regstellende aksie
}

\author{
E.J. de Beer \\ Skool vir Kerkwetenskappe \\ Potchefstroomkampus \\ Noordwes-Universiteit \\ POTCHEFSTROOM \\ E-pos: edmunddebeer@lantic.net
}

\begin{abstract}
A theological ethical judgment of affirmative action

In the period directly before and after 1994 much consideration was given to the position of the South African labour market. It was clear that some form of affirmative action had to be instituted. In this article different ways in which affirmative action has been applied since 1994 are studied, as well as the effects thereof. Affirmative action has made it possible for many workers to occupy positions that they otherwise would not have received. Other workers have been negatively affected by affirmative action. How should this be judged? In this article a number of Biblical principles regarding labour are posed. The current application of affirmative action is judged against these principles.
\end{abstract}

\section{Opsomming}

\section{'n Teologies-etiese beoordeling van regstellende aksie}

Baie besinning oor die stand van die Suid-Afrikaanse arbeidsmark het in die tydperk direk voor en na 1994 plaasgevind. Uit die besinning was dit duidelik dat een of ander vorm van regstellende aksie moes plaasvind. In hierdie artikel word ondersoek ingestel na die verskillende maniere waarop regstellende aksie sedert 1994 toegepas word, en wat die gevolg daarvan is. Talle werkers het op grond van regstellende aksie poste bekom, wat hulle andersins nie sou bekom het nie. Regstellende aksie het ander werkers weer negatief geraak. Hoe moet hieroor geoordeel word? In hierdie artikel word 'n aantal Bybelse uitgangspunte wat betrekking op arbeid het, gestel. Die huidige toepassing van regstellende aksie word aan die hand van hierdie uitgangspunte beoordeel. 


\section{Inleiding}

Vanaf 1994 speel regstellende aksie 'n belangrike rol in die SuidAfrikaanse arbeidsmark. Regstellende aksie handel oor pogings om werknemers in Suid-Afrika breedweg verteenwoordigend van die land se bevolking te maak. Dit is veral daarop gerig om swart mense, vroue en gestremde werknemers 'n groter aandeel in die Suid-Afrikaanse arbeidsmark te laat bekom. Besinning oor die noodsaak vir regstellende aksie het die toepassing daarvan voorafgegaan (vgl. Van Wyk, 1996:174). Uit die besinning was dit duidelik dat regstellende aksie op een of ander manier móés plaasvind. Verskillende maatreëls is sedertdien geneem, om regstellende aksie toe te pas. In hierdie artikel word ondersoek ingestel na die toepassing van regstellende aksie en wat die uitwerking daarvan is. Die toepassing word vanuit 'n Bybelse perspektief beoordeel.

In hierdie artikel word gekonsentreer op die toepassing van regstellende aksie met betrekking tot swart- en vroulike werknemers. Die uitwerking van regstellende aksie op gestremdes word nie ondersoek nie, omdat minder as $1 \%$ van die werknemers in Suid-Afrika uit hierdie groep kom, en regstellende aksie tot dusver nog weinig invloed op hierdie groep gehad het (Mdladlana, 2003:15).

\section{Agtergrond}

Die begrip regstellende aksie impliseer dat 'n fout van die verlede reggestel moet word. Die aanhef tot die Wet op Gelyke Indiensneming (South Africa, 1998a) spel die fout wat reggestel moet word duidelik uit:

... as a result of apartheid and other discriminatory laws and practices, there are disparities in employment, occupation and income within the national labour market; and

that those disparities create such pronounced disadvantages for certain categories of people that they cannot be redressed simply by repealing discriminatory laws ...

As deel van apartheid is wette aangeneem wat mense van verskillende rasse verplig het om in sekere gebiede te woon. Hierdie bepalings het dit vir swart werkers moeilik gemaak om deel te hê aan die openbare arbeidsmark. Die situasie is vererger met die Wet op Nywerheidsversoening (1956) wat bepaal het dat sekere beroepe 
net vir sekere rasse gereserveer word. Dit het ongeveer $2 \%$ van die werksgeleenthede geraak (Giliomee, 2003:510).

Regstellende aksie is nie alleen teen apartheid se nalatenskappe gemik nie, dit is ook daarop gerig om diskriminasie tussen manlike en vroulike werkers uit te wis. In die verlede het dit dikwels gebeur dat manlike werkers beter vergoed is as vroulike werkers wat dieselfde werk verrig het. In 1993 het Suid-Afrika die Konvensie oor die uitwissing van alle vorme van diskriminasie teen vroue onderteken. Ondertekenaars van die konvensie onderneem om wetgewing daar te stel wat diskriminasie teen vroue verbied, en toe te sien dat vroue gelyke toegang tot indiensneming het (United Nations, 1979). Gelyke toegang tot indiensneming impliseer dat vroue dieselfde vergoeding as mans in dieselfde poste sal ontvang. In die tydperk ná 1994 het die regering verskeie stappe gedoen om uitvoering aan dié konvensie te gee.

Die stappe wat deur die regering gedoen is, het nie slegs ten doel om die indiensneming van vroue te verbeter nie, maar ook die indiensneming van swart mense en gestremdes. Die aanhef van die Wet op Gelyke Indiensneming (South Africa, 1998a) stel dit dat daar ongelykhede in indiensneming, beroepe en inkomste in die SuidAfrikaanse werkmag is ten opsigte van swart werkers en vroue in senior- en bestuursposte. Dat dit inderdaad so is, blyk uit die feit dat die Suid-Afrikaanse werkersmag byvoorbeeld in 1999 uit $79 \%$ swart werkers bestaan het, terwyl slegs $44 \%$ van hulle in bestuursposisies was. Vroue het $40 \%$ van die werkersmag uitgemaak, maar het $27 \%$ van die bestuursposte beklee (Thomasson, 1999).

Ten einde die Suid-Afrikaanse werkersmag meer verteenwoordigend van die bevolking te maak, bepaal die Handves van Menseregte, soos opgeneem in die Suid-Afrikaanse Grondwet (South Africa, 1996), dat die staat of enige persoon nie mag diskrimineer teen 'n persoon oor onder andere sy/haar geslag nie. Die Handves bepaal ook dat wetlike en ander maatreëls getref mag word om mense, of kategorieë mense, te beskerm of te bevorder wat benadeel is deur onregverdige diskriminasie, ten einde die verkryging van gelykheid te bevorder.

\section{Regstellende aksie teologies noodsaaklik}

Regstellende aksie word in Suid-Afrika toegepas op grond van grondwetlike bepalings. Regstellende aksie is ook op grond van teologiese gronde noodsaaklik. 
Geregtigheid en regverdigheid is belangrike Ou-Testamentiese begrippe. Omdat God sy verbond hou, tree Hy regverdig teenoor sy volk op. Sy regverdige optrede teenoor sy volk bepaal hoe sy volk teenoor Hom en teenoor mekaar moet optree (Garlington, 1995:743). Wanneer iemand benadeel word, vereis geregtigheid dat reg moet geskied teenoor die persoon wat ly (Pop, 1987:257). Reg moet so toegepas word dat die persoon wat onreg gely het sonder skade verder kan leef (Koch, 1984:514).

In die Nuwe Testament word God se geregtigheid geopenbaar in Jesus Christus. Sondaars wat in Jesus Christus as Verlosser glo, word deur sy kruisdood met God versoen (Rom. 3:21-26). Dit gebeur omdat die ou mens saam met Hom gesterf het en die nuwe mét Hom opgestaan het. As nuwe mense moet gelowiges hulself "as werktuie van geregtigheid in diens van God stel" (Rom. 6:13 OAV). Prakties beteken dit dat reg en geregtigheid in die samelewing vir gelowiges belangrik is. Om hierdie rede behoort die regstelling van die verkeerde op die arbeidsterrein ook vir gelowiges belangrik te wees.

\section{Toepassing van regstellende aksie}

Sedert die Handves van Menseregte aangeneem is, is verskeie wetlike stappe gedoen om regstellende aksie toe te pas. Die belangrikste wette wat sedertdien aangeneem is, is die volgende:

- Die Wet op Arbeidsverhoudinge (South Africa, 1995) bepaal dat vakbonde nie teen persone mag diskrimineer op grond van geslag nie.

- Die Wet op Basiese Diensvoorwaardes (South Africa, 1997) is ewe van toepassing op manlike as vroulike werkers.

- Die Wet op Gelyke Indiensneming (South Africa, 1998a) het onder meer ten doel om die konstitusionele reg van gelykheid te bevorder, onregverdige diskriminasie in indiensneming uit te skakel, die gevolge van diskriminasie te herstel en 'n werkersmag daar te stel wat die inwoners van die land breedweg verteenwoordig. Die wet is in besonder daarop gerig om die indiensnemingstruikelblokke wat swart mense, vroue en gestremdes in die werksopset ondervind, te verwyder. Die wet vereis nie dat huidige werkers uit die nie-aangewese groep (wit mans) uit hulle werk geplaas sal word of die moontlikheid van bevordering ontneem sal word nie. Die wet vereis wel dat indien 'n swart en ' $n$ wit persoon met dieselfde kwalifikasies vir 'n pos 
aansoek doen, die swart aansoeker die pos moet kry (Van Rooyen, 2004:3).

- Die Wet op Vaardigheidsontwikkeling (South Africa, 1998b) het ten doel om die groot verskil in vaardighede van werkers reg te stel en gelykheid in die werkplek te bevorder (Hlangani, 2000:16).

- Die Wet op die Raamwerk vir Voorkeurverkrygingsbeleid (South Africa, 2000) voorsien dat nasionale, provinsiale en munisipale regerings ' $n$ voorkeurverkrygingsbeleid daar sal stel, waarvolgens kontrakte nie noodwendig aan die goedkoopste tenderaar toegestaan sal word nie. Die doel van dié Wet is om kontrakte toe te staan aan mense teen wie histories gediskrimineer is op grond van ras, geslag of gestremdheid.

- Die doel van die Wet op Swart Ekonomiese Bemagtiging (South Africa, 2003) is om onder andere swart mense in die land se ekonomie te laat deel, ' $n$ omvattende verandering in die rassesamestelling van eienaarskap en bestuurstrukture te bewerk en ook ' $n$ verandering in die rassesamestelling van geskoolde werkers in bestaande besighede te bewerk. Die wet wil in besonder swart vroue help om bestaande en nuwe besighede te besit. Die aanhef tot die wet stel dit dat die wet nodig is, omdat die Suid-Afrikaanse ekonomie laer as sy potensiaal presteer, vanweë die lae inkomstevlakke van die meeste werkers. Die staat hoop om met swart ekonomiese bemagtiging die verskil in inkomste wesenlik te verklein (Gumede \& Qoza, 2003:1).

Regstellende aksie word nie alleen toegepas waar wetgewing dit verplig nie. Die Departement van Openbare Werke beskou homself byvoorbeeld as die regering se grootste agent vir die bevordering van swart bemagtiging, omdat die staat eiendom ter waarde van R120 miljard het wat in stand gehou en herstel moet word (Duvenhage, 2001). Die staat bevorder swart bemagtiging ook in die lewering van professionele dienste. 'n Rooster waarvolgens werk aan argitekte, ingenieurs en bestekopnemers toegeken word, is sodanig opgestel dat bemagtigingsgroepe gouer as gevestigde maatskappye in aanmerking kom om weer werk vir die staat te doen (Van Rooyen, 1999:11). In 2003 het die regering aangekondig dat R10 miljard vir die daaropvolgende vyf jaar vir swart bemagtigingsbeleggings bewillig is. Dit is ook die staat se voorneme om binne vyf tot tien jaar minstens $50 \%$ van alle staatsbeheerde ondernemings aan swart mense te besorg, en dieselfde persentasie van die staat se aankope by swart ondernemings te doen (Sathekge, 2003:13). 
Ook in die privaatsektor word verskeie pogings aangewend om regstellende aksie toe te pas. Verskeie sektore in die ekonomie het reeds onderneem om swart bemagtiging toe te pas. 'n Voorbeeld hiervan is die finansiële sektor. Groot banke het onderneem om gedeeltes van hulle besigheid aan swart beleggers te verkoop (West \& Bloomberg, 2003:1). Hulle het ook onderneem om teen 2014 reeds $70 \%$ van hulle aankope by swart bemagtigingsmaatskappye te doen. Finansiële instellings het verder onderneem dat $4,5 \%$ van hulle personeelkomponent swart matrikulante sal wees wat in leerlingskappe aangestel gaan word, terwyl maatskappye $1,5 \%$ van hulle totale salarisuitgawes aan die ontwikkeling van swart vaardighede van swart mense sal bestee (Le Roux, 2003:2). Finansiële instellings sal teen 2010 swart eienaarskap van $25 \%$ hê (Anon., 2003a:15). Sektore soos die mynbou en petrochemiese bedryf is met soortgelyke planne besig.

\section{Faktore wat regstellende aksie belemmer}

Navorsing (RGN, 1999a; Anon., 2006a) dui daarop dat dit baie moeilik is om regstellende aksie toe te pas in sekere beroepsrigtings, omdat daar 'n tekort aan swart werknemers in dié rigtings is. Die probleem word vererger deur die feit dat slegs $45 \%$ van die grade wat jaarliks toegeken word deur swart studente verwerf word. Hierdie kwalifikasies is gemiddeld op 'n laer vlak as dié van blankes en dit is ook gewoonlik in rigtings waar daar reeds 'n ooraanbod van gekwalifiseerdes is. Daar is veral 'n tekort aan swart gegradueerdes in die natuurwetenskappe, ingenieurswese, boubedryf (byvoorbeeld argitekte), gesondheid (behalwe verpleging), regte en alle ekonomiese en bestuurwetenskappe (behalwe administrasie).

\section{Uitwerking van regstellende aksie}

Die toepassing van regstellende aksie het reeds verskeie gevolge gehad op die poste wat werknemers beklee. Sommige werkers kan op grond van regstellende aksie poste bekom wat hulle onder gewone omstandighede nie sou kon bekom het nie.

Die volgende voorbeelde word genoem om aan te dui hoe regstellende aksie tot dusver sommige werkers se posisies positief beïnvloed het:

- Die regering het sedert 1994 heelwat gedoen om 'n voorbeeld te stel in die bereiking van geslagsgelykheid. Teen Junie 1999 was $30 \%$ van die parlementslede vroue. Van die 27 ministers en twaalf adjunk-ministers was vyftien vroue (Camerer, 2000:12). 
Daar is ook amptenare aangestel om 'n wakende oog te hou oor die bestuur van geslagsgelykheid in die verskillende staatsdepartemente (Seale, 2001:9). Dit blyk dat die regering in sy pogings slaag om geslagsgelykheid onder staatsamptenare te bereik. Teen die einde van 2001 was $52 \%$ van die meer as een miljoen werkers in diens van die staat vroue. Vroue het byna $30 \%$ van die bestuursposisies beklee, terwyl vroue $21 \%$ van alle aanstellings in senior bestuursposisies uitgemaak het (Misbach, 2002:4).

- Dit blyk dat veranderinge ook in die privaatsektor plaasvind. Uit verslae van werkgewers wat meer as 150 werkers in diens het, blyk dit dat net in 2000 reeds 45610 poste wat deur mans beklee is, verlore gegaan het, terwyl daar 'n netto wins van 17397 in vroueposte was. Op bestuursvlak het vroue 'n netto wins van 1201 poste gehad (Mittner, 2001:11). Navorsing van die RGN (1999b) toon aan dat aan die begin van die negentigerjare daar 'n $10 \%$-gaping was in die vergoeding tussen mans en vroue op die vlak van geskoolde en halfgeskoolde werkers. Hierdie verskil het tot 5\% verklein (Erasmus, 2001:6).

- Die swart elite in die land het binne vyf jaar hulle inkomste verdubbel tot 'n totaal van R13,5 miljard. 'n Studie toon ook aan dat $23 \%$ van die land se rykste mense in 2001 swart mense was (Anon., 2001:7). In 2005 was 35,7\% van die werknemers in die hoë inkomste groep (verdienste hoër as R153 601 per jaar) swart. Dit is byna drie keer meer as die $13 \%$ in 1998. Daar was ook in die middelinkomstegroep (jaarlikse verdienste tussen R38 401 en R153 600) 'n groei. In 1998 het swart werknemers 43,1\% van hierdie groep uitgemaak. In 2004 was hulle aandeel $58,8 \%$ (Theunissen, 2005).

- Swart ekonomiese bemagtiging het reeds gehelp dat enkele swart sakemanne reuse bedrae geld verdien het. Tagtig persent van die waarde van die tien grootste swart bemagtigingstransaksies is deur net drie sakemanne gedoen. Hierdie drie sakemanne was betrokke by vyf van die tien grootste transaksies. Die waarde daarvan was R24,6 miljard (Dasnois, 2004a:12).

- Reeds voor die aanname van die Wet op die Raamwerk vir Voorkeurverkrygingsbeleid (South Africa, 2000) het die staat 'n Regstellende Voorkeurverkrygingsbeleid gehad. In die uitvoering van dié beleid is meer as R600 miljoen se projekte aan swart 
hoofkontrakteurs toegeken (Nasionale Departement van Openbare Werke, 2001).

- Regstellende aksie stel sommige swart werkers in staat om met die minimum insette en risiko kontrakte en kwotas te ontvang. Die regering se beleid om voorkeur te gee aan swart maatskappye het daartoe gelei dat wit maatskappye van swart frontmaatskappye gebruik maak om staatskontrakte te bekom (Swart, 1998:1). Die voorkeurbeleid het ook veroorsaak dat sommige swart groepe wat hoër getender en die werk gekry het, daarna wit ondernemings wat laer getender het, nader om die werk te doen. Hulle steek dan die verskil in hulle sakke (Booyens, 1997:1). Dieselfde gebeur ook in die visbedryf waar swart vissers visvangkwotas verkry, maar dit nie self benut nie en aan andere verkoop (Zietsman, 2001).

- Teen 2002 het die regering naby sy oogmerk gekom, om die staatsdiens ras- en geslagsverteenwoordigend te maak. Die staat het toe reeds $85 \%$ swart werknemers in diens gehad. Volgens die minister van staatsdiens en administrasie moes daar nog 'n 5\%aanpassing gemaak word in die vermindering van blanke werknemers en die vermeerdering van swart werkers. Op bestuursvlak was $60 \%$ van die werknemers swart, wat $10 \%$ meer was as die gestelde teiken (Misbach, 2002:4).

- 'n Verslag van Deloitte en Touche Capital Corporation dui aan dat swart bestuurders op middelbestuursvlak al hoe meer word, en wit bestuurders minder. Op senior- en hoofbestuursvlak is daar egter nie 'n groot verandering nie, omdat daar 'n groot tekort is aan mense met gepaste kwalifikasies en ervaring, veral vir senior- en hoofbestuursposte (Anon., 2003b:2).

- Swart bestuurders slaan tans munt uit die tekort aan geskikte bestuurders. 'n Ondersoek by 'n honderd maatskappye het getoon dat maatskappye meer betaal aan professionele swart werknemers ten einde aan die vereistes van gelyke indiensneming te kan voldoen. Swart werknemers op middelbestuursvlak ontvang gemiddeld $16 \%$ meer, senior bestuurders kry gemiddeld $16,4 \%$ meer en uitvoerende amptenare, besturende direkteure en algemene bestuurders ontvang 19,6\% meer. Daar is gevalle waar besighede tot $40 \%$ meer betaal aan swart werknemers om hulle dienste te bekom en te behou (Theunissen, 2005). 
- 'n Tekort aan geskikte swart direksielede veroorsaak ook in baie gevalle dat dieselfde persoon in verskeie maatskappye se direksies dien (Mashalaba, 2003:23).

- In baie gevalle waar swart bemagtiging toegepas word, word maatskappye en die bestuur daarvan aan persone gegee wat gekies word op grond van hulle politieke agtergrond en hulle verbintenisse in die politiek, sonder dat hulle noodwendig weet hoe om die bates waaroor hulle beheer ontvang, te bestuur. Hulle loop ook nie persoonlike risiko's nie (Mbeki, 2003:15), omdat hulle geld ontvang van spesiale konsortiums (Sefara, 2003:9).

- In 2004 is swart bemagtigingstransaksies ter waarde van minstens R62 miljard beklink. In 2005 is 'n verdere R55 miljard se transaksies gesluit. Hierdie transaksies se waardes is bekendgemaak, maar daar het ook transaksies plaasgevind waarvan die waarde nie bekendgemaak is nie (Anon., 2006a).

Uit bogenoemde voorbeelde is dit duidelik dat regstellende aksie reeds tot gevolg het dat talle vroue en swart mense nou poste beklee waarvoor hulle nie voorheen sou gekwalifiseer het nie. Regstellende aksie het egter op sommige werkers se arbeid en die vergoeding wat hulle daarvoor ontvang 'n negatiewe uitwerking. Onderstaande is voorbeelde hiervan.

- Sommige werkgewers gebruik versnelde bevorderingsprogramme ten einde hulle werkers so gou moontlik verteenwoordigend van die land se bevolking te maak. Dit gebeur dat maatskappye blanke aansoekers oorslaan en ter wille van die nakoming van regstellende aksie swart werkers soek, al het hulle minderwaardige kwalifikasies of geen ondervinding nie (Kenny, 2001:13).

- Daar is maatskappye wat wette oortree in hulle poging om regstellende aksie toe te pas. Eskom, Rand-Water en die SuidAfrikaanse Polisiediens het hulself al skuldig gemaak aan diskriminasie teen blanke werknemers (De Lange, 1999:1; Tempelhoff, 2003:2; Stuart \& Maluleke, 2003:1; Mabasa, 2002:2).

- Regstellende aksie was ook die oorsaak van diskriminasie tussen werkers van verskillende rasse binne die aangewese groep. Volgens die Wet op Gelyke Indiensneming (South Africa, 1998a) kwalifiseer swart mense om deur regstellende aksie bevoordeel te word. Die wet definieer swart mense as Afrikane, kleurlinge en Indiërs. In 2006 het die Kaapse arbitrasiehof bepaal dat Afrikane 
bo kleurlinge en ander groepe bevoordeel moet word (O'Connor, 2006:7; Anon., 2006b:8).

- Regstellende aksie was die rede waarom sommige uitvoerende direkteure van Nampak tussen $15 \%$ en $25 \%$ van hulle aansporingsbonusse verbeur het. Hulle het dit verloor, omdat hulle nie toegesien het dat die maatskappy sy regstellende aksieteiken haal nie. Slegs $18 \%$ van die bestuurders was Afrikane, terwyl die teiken $20 \%$ was (Dasnois, 2004b:2).

- Regstellende aksie benadeel nie alleen die bevordering en gepaardgaande vergoeding van sommige wit werkers nie. Dit kan ook tot hulle werksverlies lei. Santam Lewens het in 2003 te kenne gegee dat hy sy werksmag met 350 sou verminder en dat diensbillikheid (regstellende aksie) ' $n$ rol sou speel in die proses om die werksmag te verklein. Hieruit word afgelei dat die werksmag op so 'n manier verklein wou word dat die maatskappy in 'n groter mate die land se bevolking weerspieël (De Lange, 2003:8).

- Maatskappye wat gedwing word om kunsmatige personeelvermindering toe te pas, staan gevaar om vanweë ondoeltreffendheid nie die mas teen buitelandse mededinging op te kom nie. Dit noop hulle om hulle hoofkantore na die buiteland te verskuif, waarvandaan hulle dan hulle bedrywighede verder bestuur (Booyens, 1997:1).

Regstellende aksie was ook reeds die oorsaak van 'n verlaging in werksgehalte:

- In 1998 het die regering R200 miljoen bewillig vir die aankoop van handboeke vir skole. Tenders vir die lewering van dié boeke is aan klein maatskappye toegeken, om swart bemagtiging te bevorder. Die maatskappye kon vanweë 'n verskeidenheid probleme nie hulle kontrakte na behore nakom nie, met die gevolg dat skole nie betyds hulle handboeke ontvang het nie (Joubert, 1999:1).

- 'n Nasionale organisasie wat hom op padveiligheid toespits, Drive Alive, het die mislukking van die 2002/2003 Arrive Alive-veldtog aan regstellende aksie toegeskryf. As deel van regstellende aksie is aanloklike pakkette aan kundige en ervare personeel aangebied. Die kundige verkeersbeamptes is deur onkundiges vervang (Oosthuizen, 2003:1). 
Regstellende aksie het daartoe bygedra dat werkers in alle sektore meer verteenwoordigend van die land se bevolking is. Talle vroue en swart werkers het hierby gebaat deur onder meer hoër vergoeding vir hulle arbeid te ontvang. Aan die ander kant word veral wit manlike werkers se vergoeding vir hulle arbeid nadelig geraak, omdat dit vir hulle moeiliker is om werk te vind of hoër poste te bekom.

\section{Bybelse uitgangspunte}

By die beoordeling van regstellende aksie behoort die ondergenoemde Bybelse uitgangspunte in aanmerking geneem te word.

\subsection{Werk as deel van menswees}

Die mens is na die beeld van die altyd werksame God (Joh. 5:17; Ef. 1:20-22; HK 19:50) geskape. Arbeid is een van die eienskapppe waardeur die mens God se beeld vertoon (Gremmels, 1978:366; Van Wyk, 1988:45). Nou verwant aan die mens wat na God se beeld geskape is, is God se doelwitte met die mens. Een van die doelwitte was dat die mens oor God se skepping moet heers (Gen. 1:26; 2:15). Ooreenkomstig hierdie doelwit het God die mens die opdrag gegee om die aarde te onderwerp en daaroor te heers (Gen. 1:28). Daarom het die mens die reg om te werk (Norval, 1966:110; Petersen, 1990:180; Heyns, 1986:255).

\subsection{Arbeid en geslag}

God het die mens, manlik en vroulik, na sy beeld geskape. Hy het albei geseën en die opdrag gegee om die aarde te bewoon en te bewerk. Albei geslagte tree op as verteenwoordigers van God op aarde. Die skepping van die vrou as hulp van die man (Gen. 2:18) beteken dat sy hom ook in sy werk sal bystaan. Saam moet hulle die tuin bewerk en bewaar (Van Wyk, 1988:63, 116).

Daar is in die lig van die skepping van die verskillende geslagte geen arbeidsreservering van die een geslag teenoor die ander nie (Heyns, 1986:276). Hoewel daar vanweë die verskil in geslag tog 'n noodwendige verskil in werksaamhede is (vroue bring kinders in die wêreld en is veral in die beginjare ten nouste by hulle kinders betrokke, en mans is weer fisies sterker en is noodwendig meer betrokke by werk wat fisiese arbeid vereis - vgl. Bienert, 1956:118), is daar in beginsel geen werksreservering tussen die twee geslagte nie. 


\subsection{Arbeidsontplooiing}

Die opdrag om die aarde te bewerk, gee aan die mens 'n baie wye arbeidsveld. Dit impliseer dat die hele aarde se hulpbronne deur die mens ontdek en bewerk kan word (vgl. Johannes Paulus II, 1981: par. 14). Om hierdie omvangryke taak na te kom, het God mense nie almal dieselfde geskape nie, maar aan elkeen sy eie eienskappe, talente, vermoëns en belangstellings gegee (Antonides, 1989:9). Dit is dan ook die grondslag vir die arbeidsverdeling en arbeidsontplooiing wat oor eeue heen besig is om plaas te vind (vgl. Duvenage, 1957:145).

Reeds vroeg in die Bybel word melding gemaak van die diversifisering van arbeid. Kaïn se seun het 'n stad gebou en sy nakomelinge het veeboere, musikante en metaalwerkers geword (Gen. 4:17, 20-22). Noag het 'n wingerd aangelê (Gen. 9:20), terwyl sy nageslag 'n hoë gebou opgerig het (Gen. 11:3; Dautzenberg, 1978:345).

Arbeidsontplooiing vind nie gelykmatig of los van ander gebeure plaas nie. Verskillende omstandighede dra by tot arbeidsontplooiing en die ontwikkeling van verskillende beroepe. Ekonomiese en politieke ontwikkeling het 'n direkte invloed op die ontwikkeling van beroepe. Die Israeliete was aanvanklik bestaansboere wat deur middel van ruilhandel bekom het wat hulle nie self geproduseer het nie. Met die instelling van die koningskap het 'n amptenary (paleisen landsadministrasie) en 'n offisiële priestergroep ontwikkel, wat nie meer self landbouprodukte geproduseer het nie. 'n Vinnige bevolkingstoename het verdere beroepsdifferensiasie meegebring (Van Heerden, 1991:224).

\subsection{Onderhoudsperspektief}

Die mens moet die aarde bewerk, sodat hy kan leef van die vrug van sy arbeid. In Genesis 1:28 word die mens geseën en beveel om te vermeerder, die aarde te bewoon en te bewerk en oor die diere te heers. In die volgende vers gee God al die plante wat saad gee en bome wat vrugte en saad gee as kos vir die mens. 'n Mens vind dieselfde noue verbintenis tussen arbeid en voedsel in Genesis 2:15 en 16. Daar is dus ' $n$ innerlike samehang tussen die opdrag om die tuin van Eden te bewerk en te bewaar, en die eet van die vrugte in die tuin (Velema, 1980:7).

Reeds in die tuin van Eden is die beginsel vasgelê dat die mens geregtig is om vergoed te word vir sy arbeid, sodat hy kan leef. Elke 
werker het reg om sonder inagneming van ras of geslag vergoed te word vir sy arbeid, omdat dit hom en sy afhanklikes in staat stel om te lewe (Petersen, 1990:182). Dit impliseer ook dat die mens nie kan verwag om te eet as hy nie daarvoor gewerk het nie.

\subsection{Die reg op vergoeding vir arbeid}

Die mens het 'n reg op lewe, omdat God hom geskep het, asem in hom geblaas en lewe aan hom gegee het. Hierdie lewe word in stand gehou deur kos, want daarsonder sterf die mens. Hy verkry sy voedsel deur arbeid. Daarom is die voorsiening van voedsel 'n elementêre arbeidsdoel. Stoker (1972:54) stel dit dat die mens 'n ontiese reg op lewe het en dus ook op arbeid waardeur hy hom van voedsel kan voorsien. Hierdie reg vorm die sin en begronding van arbeidersloon.

Die reg op vergoeding vir arbeid word op verskillende plekke in die Bybel bevestig, met die uitdrukking dat die arbeider sy loon werd is. Hierdie reg geld vir mens (Luk. 10:7) en dier (Deut. 25:4).

\subsection{Die staat en arbeid}

Dit is die owerheid se plig om tot beswil van sy onderdane te regeer (Rom. 13:4). Dit impliseer dat elke owerheid maatreëls sal tref om te verseker dat die onderdane die geleentheid sal hê om te werk en in hulle behoeftes te voorsien.

\subsection{Sondeval}

Die sondeval het 'n geweldige uitwerking op arbeid. Arbeid self is nie vervloek nie, maar die mens se werkplek, die aarde, is vervloek (Gen. 3:17). Die vervloeking van die aarde het 'n uitwerking op die mens, omdat die mens en die aarde op mekaar gerig is (Van Wyk, 1988:63). Daarom het die vervloeking van die aarde 'n direkte uitwerking op die mens se arbeid en ook op die vrug wat hy vir sy arbeid ontvang (Velema, 1980:8; Van Wyk, 1988:65). Die gevolg van die sondeval word vererger deur die mens wat ook op die arbeidsterrein 'n sondaar geword het (Norval, 1966:120). Dit het 'n universele uitwerking op die arbeidsopdrag (Johannes Paulus II, 1981: par. 39).

Die gevolg van die sondeval is dat die mens sy lewe lank met swaarkry 'n bestaan uit die aarde sou maak. Die swaarkry neem verskillende dimensies aan. Dorings en dissels spruit uit (Gen. 3:18) wat die werk moeilik maak, nie net vir boere nie, maar vir alle 
beroepe. Dit is alleen met moeisame werk dat die mens 'n bestaan maak (Agrell, 1976:12; Bienert, 1956:59). Dit manifesteer in die pyn, ellende, teleurstelling, armoede en werkloosheid wat deel van die arbeidsopset geword het (Antonides, 1989:8).

Hoewel die mens as gevolg van die sondeval nie deur God vervloek is nie (Velema, 1980:8), het die sondeval wel verwydering tussen God en die mens gebring. Die mens wat van God vervreemd is, ondervind arbeidsmoeite en -ellende, omdat sy arbeid aan God se Heer-skap onttrek word (Vos, 1986:3). Die mens wil nou self skepper wees, sy eie wette bepaal en God uitskakel (Duvenage, 1983:5). Van Wyk, (1996:166) wys daarop dat Christus nie net gekom het vir die "redding van 'n siel" nie, maar dat die hele kosmos, wat die totale mens insluit, deel is van sy verlossingswerk. Deur die Heilige Gees maak Hy mense nuut. Hulle word gelykvormig gemaak aan God se Beeld, Jesus Christus (Velema, 1980:11). Dit het ook 'n uitwerking op die mens se werk.

\subsection{Die "reeds" en "nog nie" van Christus se verlossingswerk}

Jesus Christus het die mens kom verlos van die sonde en die gevolge van die sondeval. Die herskeppingswerk het begin, maar is nog nie voltooi nie. Dit is belangrik om daarop te let dat al het Jesus Christus na die aarde toe gekom en al is Hy gekruisig en het Hy die dood oorwin en opgevaar na die hemel toe, beteken dit nie dat die herskepping voltooi is nie. Die mensdom ly steeds as gevolg van die sondeval (Coetzee, 1984:238). Dit geld ook op die arbeidsterrein.

Al is die mens nog nie van alle lyding verlos nie, het die kruis nou reeds 'n uitwerking op die gelowige werker. Deur die kruis is die gelowige 'n nuwe mens. Sy arbeid hoort by sy nuwe lewe, al is dit in 'n ou wêreld wat wag om herskep te word (Bienert, 1956:189). Die werker wat deur Christus verlos is, sien sy werk in 'n ander lig as die ongelowige. Die las van die arbeid het vir die versoende ligter geword (Norval, 1966:123). Sy ingesteldheid teenoor arbeid is anders.

Die sondeval het ook die verhouding tussen die mens en sy medemens versteur. Hierdie versteuring is duidelik uit die egoïsme, wrywing, ongeregtigheid, uitbuiting, opstand teen gesag en valse vryheidsreg wat op die arbeidsterrein neerslag vind (Duvenage, 1983:4). Die versteuring lei tot die arbeidsprobleme wat werkers en werkgewers ondervind (Norval, 1966:124). 


\section{Beoordeling van regstellende aksie}

\subsection{Die noodsaak van regstellende aksie}

God het aan alle mense die opdrag gegee om te werk en het ook bepaal dat die mens uit die vergoeding wat hy vir sy werk ontvang, sal leef. Dit is 'n universele bepaling wat vir mense van alle rasse en albei geslagte geld. Daarom behoort daar in beginsel geen werksreservering tussen die arbeid wat werkers van verskillende rasse of geslagte verrig, te wees nie.

Werkers ontvang nie almal dieselfde vergoeding vir hulle arbeid nie. Produktiwiteit, werksomstandighede, kundigheid, werksgehalte en die samelewingskonteks waarbinne werk verrig word, is regverdigbare faktore wat ' $n$ invloed het op die vergoeding wat werkers ontvang. Ras en geslag behoort in beginsel nie ' $n$ rol te speel by arbeid of die vergoeding wat werkers daarvoor ontvang nie. Voor 1994 het dit gebeur dat vroue soms laer vergoed is vir dieselfde arbeid wat deur mans verrig is. Die verskil in vergoeding vir dieselfde arbeid het verder gestrek as ' $n$ verskil in die vergoeding tussen mense van verskillende geslagte. Voor 1994 het werkers van verskillende rasse verskillende vergoeding ontvang, ten spyte daarvan dat hulle dikwels dieselfde werk verrig het. Die verskil in vergoeding tussen verskillende rasse is vererger deur werksreservering, wat sekere werksgeleenthede tot sekere rasse beperk het.

Voor en na die regeringsverandering van 1994 is vanuit verskeie oorde gewys op die noodsaak van regstellende aksie, met die doel om "gelyke geleenthede vir alle burgers te fasiliteer en verontregte gemeenskappe te kompenseer vir agterstande" (Van der Merwe, 1994:3). Vanuit 'n Bybelse perspektief is dit duidelik dat een of ander vorm van regstellende aksie sou moes plaasvind, om toe te sien dat werkers van verskillende geslagte en rasse gelyke toegang tot alle werksgeleenthede kon kry en vir hulle arbeidsinset vergoed word, sonder inagneming van hulle geslag of ras. Reeds voordat met regstellende aksie begin is, is voorsien dat die staat die leiding sou moes neem met die implementering van wetgewing en programme vir regstellende aksie. Die privaatsektor sou nie hiervan uitgesluit wees nie en sou ook regstellende aksie moes toepas (Van der Merwe, 1994:12-16).

Die regering het besluit om regstellende aksie op so 'n wyse toe te pas dat die arbeidsektor uiteindelik 'n weerspieëling van die land se bevolking moet wees. Om dié doel te bereik, is drie groepe mense 
aangewys wat kwalifiseer om deur regstellende aksie bevoordeel te word, naamlik vroue, swart mense en gestremdes. Regstellende aksie is tot dusver veral ten opsigte van vroue en swart mense toegepas.

\subsection{Regstellende aksie en vroue}

Apartheid en diskriminerende wette word gewoonlik voorgehou as die belangrikste redes waarom daar vóór 1994 geslagsongelykheid in indiensneming was. Apartheid het ' $n$ rol gespeel in die vergoeding wat swart vroue ontvang het, omdat baie van hulle nie veel bewegingsvryheid gehad het nie, maar in tuislande moes bly en daar moes werk soek. Apartheid was egter nie die enigste rede waarom mans voor 1994 inderdaad beter vergoeding as vroue ontvang het nie.

Arbeidsverdeling tussen mans en vroue is in Suid-Afrika (soos elders in die wêreld) 'n eeue oue verskynsel, wat reeds by jagters en bestaansboere voorgekom het. In dié samelewings het die arbeid van die verskillende geslagte mekaar gekomplementeer. Ekonomiese ontwikkeling en beroepsontplooiing het dit die afgelope eeu toenemend moontlik gemaak dat mans en vroue dieselfde beroepe kan beoefen. Die feit dat vroue kinders in die wêreld bring en meer met hulle opvoeding gemoeid is, bring mee dat mans en vroue nie altyd presies dieselfde werk verrig nie.

Daar is in die verlede geredeneer dat mans aangewys is as die broodwinners van hulle huisgesinne, en dat die vrou se verantwoordelikheid meer op die terrein van die opvoeding van kinders en die algemene huishouding is. Om hierdie rede is gereken dat dit regverdig is dat mans meer as vroue verdien, sodat hulle in staat sou wees om hulle huishoudings te versorg (vgl. Stoker, 1973:2125; Duvenage, 1983:249). Die implikasie van hierdie standpunt was dat vroue wat werk (met die uitsondering van vroue wat broodwinners is), nie dieselfde as hulle manlike eweknieë vergoed hoef te word nie, omdat hulle nie die broodwinners is nie en hulle behoeftes nie so groot is nie. Hierdie standpunt het nie die Bybelse beginsel genoegsaam in ag geneem nie, naamlik dat die arbeidsopdrag aan die man én die vrou gegee is en dat 'n arbeider sy loon werd is, ongeag sy/haar geslag. In beginsel behoort daar nie 'n onderskeid tussen die vergoeding van vroue en mans te wees nie. Die gelyke vergoeding vir mans en vroue wat dieselfde werk doen, is Bybels meer verantwoord. 


\subsection{Regstellende aksie en ras}

Apartheid het 'n groot rol gespeel in die vergoeding wat swart mense vir hulle arbeid ontvang het. Wette het hulle verhoed om sekere poste te beklee, al het hulle die vermoë gehad om die vereiste werk te doen. Ander faktore het weens apartheid ook 'n rol gespeel in die vergoeding wat swart werkers vir hulle arbeid ontvang het, soos byvoorbeeld onderwys wat nie op dieselfde standaard as dié van blankes was nie en die ver afstande wat swart werkers na hulle werkplekke moes aflê. Dit is eties nie aanvaarbaar dat mense nie op grond van hulle arbeid vergoed word nie, maar dat ras die grootte van vergoeding bepaal. Regstellende aksie speel 'n belangrike rol, om gelyke vergoeding vir gelyke werk af te dwing.

Die toepassing van regstellende aksie is nie eenvoudig nie, omdat dit nie duidelik is wat die omvang van die benadeling weens apartheid was nie. Arbeidsontwikkeling en arbeidsontplooiing het teen die einde van die negentiende eeu baie verder onder blankes gevorder as onder die inheemse inwoners, van wie baie in daardie stadium nog 'n bestaansboerdery gevoer het. Die blankes was afkomstig uit Europa, waar arbeidspesialisasie en arbeidsonplooiing sedert die Industriële Rewolusie van die agtiende eeu geweldig gevorder het. Die ontdekking van goud en diamante het 'n plaaslike "industriële rewolusie" ontketen, en het arbeidsontplooiing onder die inheemse inwoners van Suid-Afrika baie bevorder. Apartheid het daarna die ontwikkeling en ontplooiing van arbeid onder swart werkers ten gunste van blanke werkers onderdruk. Een van die grootste probleme wat tot dusver weinig aandag geniet het met betrekking tot regstellende aksie, is die vasstelling van die omvang van die benadeling wat swart werkers weens apartheid ondervind het, gesien teen die agtergrond van die verskil in arbeidsontwikkeling en arbeidsontplooiing tussen blank en swart werkers met die instelling van apartheid. Indien daar groter duidelikheid oor bogenoemde saak was, kon dit moontlik bygedra het om te oordeel tot watter mate regstellende aksie toegepas moet word.

Ras word ' $n$ al hoe groter faktor in die toepassing van regstellende aksie, soos blyk uit verskillende oproepe wat onder andere deur die minister van arbeid gemaak is, dat alleen Afrikane vir regstellende aksie behoort te kwalifiseer (vgl. Smith, 2003:3; Oliphant, 2003:5). Die uitspraak van die Kaapse arbitrasiehof dat Afrikane bo kleurlinge bevoordeel moet word (O'Connor, 2006:7) bevestig dat ras 'n rol begin speel by die toepassing van regstellende aksie. Bogenoemde optredes plaas die regverdigbaarheid van regstellende aksie verder onder verdenking. Regstellende aksie behoort ten doel te hê om 
werkers die geleentheid te bied om ongeag geslag of ras hulle vermoëns tot voordeel van die samelewing aan te wend. Daarvoor moet hulle vergoed word. In praktyk beteken dit dat vermoëns (ongeag ras) beklemtoon sal moet word.

Die probleem word vererger deur die ongekwalifiseerde definisie van swart mense deur onder meer die Wet op Gelyke Indiensneming (South Africa, 1998a). Dié wet definieer Afrikane, kleurlinge en Indiërs as swart mense. In die praktyk beteken dit dat enige nieSuid-Afrikaanse Afrikaan, kleurling of Indiër op grond van regstellende aksie 'n aanspraak het bo 'n blanke manlike SuidAfrikaanse burger met gelykwaardige opleiding en ondervinding. In sulke gevalle kom die owerheid nie sy plig na nie, naamlik om tot die beswil van al sy onderdane te regeer.

\subsection{Regstellende aksie en vaardighede}

Met regstellende aksie probeer die regering sedert 1994 om die Suid-Afrikaanse arbeidsmark meer verteenwoordigend van die SuidAfrikaanse bevolking te maak. Die druk wat deur regstellende aksie toegepas word om vroue en swart werkers volgens hulle arbeidsinset te vergoed, is eties regverdigbaar en behoort ondersteun te word, omdat die arbeider sy loon werd is. Om gelyke lone vir gelyke werk af te dwing, is redelik eenvoudig en maklik afdwingbaar. Regstellende aksie gaan egter verder as dit. Werkgewers moet toesien dat hulle werkerskorps mettertyd die bevolking van die land ten opsigte van geslags- en rasseverteenwoordiging weerspieël. Die Wet op Gelyke Indiensneming (South Africa, 1998a) bepaal dat persone uit die aangewese groepe aangestel moet word indien hulle dieselfde kwalifikasie as aansoekers uit die nie-aangewese groep het. In die praktyk gebeur dit egter dat kandidate met minder opleiding en ervaring bó kandidate met meer opleiding en ervaring aangestel word. Hoewel die wetgewing geregverdig kan word teen die agtergrond van die benadeling wat met apartheid gebeur het, is die praktiese uitvoering daarvan in baie gevalle bevraagtekenbaar, aangesien ras en geslag by die aanstelling van werkers belangriker as vaardigheid geag word.

In die toepassing van regstellende aksie het duisende bekwame mense hulle werk verlaat of verloor, terwyl baie van hulle deur minder bekwame werkers vervang is. In baie gevalle moet konsultante gehuur word om die werk te verrig wat die onbekwame werkers veronderstel is om te doen. Waar ander werkers gehuur moet word om die werk te verrig van diegene wat eintlik daarvoor aangestel is, beteken dit dat werkers vergoed word vir werk wat 
hulle nie in staat is om te doen nie. In sulke gevalle word mense wat wel die vermoë het om die werk na behore te verrig, die geleentheid ontneem om hulle godgegewe vermoëns tot voordeel van hulself en die samelewing uit te leef.

\subsection{Regstellende aksie en die privaatsektor}

Die toepassing van regstellende aksie deur die privaatsektor laat ook ernstige etiese vrae ontstaan. Swart sakemanne bekom tans deur middel van swart bemagtiging (regstellende aksie) aandele in talle groot maatskappye. Hierdie aandeelhoudings is dikwels miljoene rand werd en word gewoonlik nie deur die nuwe aandeelhouers self gefinansier nie, maar deur middel van spesiale lenings waarin die lener (werker) die minimum risiko dra. In wese vind hier transaksies plaas sonder dat daarvoor gewerk is, of die vergoeding van vorige werk as teenprestasie aangebied is. Die deurslaggewende faktor vir hierdie transaksies is nie vermoëns nie (alhoewel dit ook 'n rol speel), maar ras.

Die feit dat enkele prominente figure die meeste baat by swart bemagtiging, laat ook verskillende vrae ontstaan: Gaan dit werklik oor die bemagtiging van swart werkers sodat hulle 'n meer direkte rol in die land se ekonomie kan speel, of is die bemagtiging van enkele prominente persone 'n soort omkopery met die oog daarop dat maatskappye hulle voortbestaan probeer verseker? Is daar werklik so min vaardighede en vermoëns onder swart mense dat slegs 'n handjievol soveel deur swart bemagtiging bevoordeel word? Waarom word nie méér mense deur bemagtiging bevoordeel nie? Swart bemagtiging skep tans werk vir slegs 'n klein klompie swart sakemanne, maar slaag nie daarin om groot getalle voorheen benadeelde mense aan die ekonomie te laat deel kry nie (vgl. Dasnois, 2004a:12). Onderliggend aan dié vrae is die feit dat arbeid onder meer daarop gerig moet wees om die naaste te dien, en nie net om eie belange uit te bou of te beveilig nie.

In sekere sektore is daar 'n tekort aan vaardighede by swart mense. Die tekort het tot gevolg dat maatskappye bereid is om hulle meer te vergoed, ter wille van die nakoming van regstellende aksie en die verkryging van werk. Ook in dié geval speel ras die deurslaggewende faktor vir vergoeding en nie die werker se arbeid nie. Waar dit gebeur, is dit eties nie regverdigbaar nie, omdat ras en nie vaardighede nie die deurslag gee in die vergoeding wat werkers ontvang. 
Regstellende aksie word verbind met die ontwikkeling van vaardighede. Waar werkers met die nodige vermoëns in die verlede verhoed is om hulle vaardighede te ontwikkel, is dit reg dat hulle die geleentheid kry om hulle vaardighede te verbeter, sodat hulle hulle vermoëns kan ontwikkel en dienooreenkomstig vergoed word. Die staat behoort met groter doeltreffendheid op te tree, sodat geld wat reeds beskikbaar is vir vaardigheidsontwikkeling, daaraan bestee word en werkers ná opleiding die geleentheid kan benut om werk te doen waarvoor hulle beter vergoeding ontvang.

Regstellende aksie bevorder tans oneerlike optrede met blanke kontrakteurs wat swart frontmaatskappye gebruik om tenders te bekom. Hierdie optrede is afkeurenswaardig en behoort nie toegelaat te word nie. Die onetiese optrede by frontmaatskappye strek verder as oneerlike kontrakteurs. Waar frontmaatskappye tenders ontvang en die werk deur ander maatskappye laat doen, ontvang die aandeelhouers van die frontmaatskappye vergoeding, sonder dat hulle daarvoor gewerk het.

\subsection{Die einde van regstellende aksie}

Voor die instelling van regstellende aksie is reeds daarop gewys dat dit 'n tydelik maatreël behoort te wees (vgl. Van der Merwe, 1994:28). 'n Afsnydatum vir regstellende aksie word al hoe noodsaakliker, gesien in die lig van die feit dat die eerste kinders wat ná 1994 met skoolonderrig begin het (toe leerders van verskillende rasse dieselfde onderrig in dieselfde skole kon ontvang), binnekort tot die arbeidsmark sal toetree. Teen 2012 sal die eerste werkers wat ná 1994 gebore is, begin werk. Hierdie mense behoort toegang tot werk en vergoeding te kry op grond van hulle belangstelling, vermoë en vaardighede, omdat hulle nie onregverdig deur apartheid bevoordeel of benadeel is nie. Indien regstellende aksie ook teenoor hulle toegepas word, word arbeid en vergoeding van nuuts af deur rassisme beïnvloed.

Regstellende aksie loop die gevaar om in 'n nuwe rassisme te ontaard. In plaas daarvan dat gekonsentreer word daarop dat mense 'n regverdige geleentheid ontvang om hulle godgegewe vaardighede en vermoëns te gebruik, speel ras 'n al hoe groter rol in die toekenning van werk en die gepaardgaande vergoeding. Die vergoeding wat werkers ontvang, behoort eerder deur faktore soos produktiwiteit, vermoëns, gevaarlikheidsvlak van die werk en aanvraag bepaal te word. 


\subsection{Regstellende aksie en die gebrokenheid van die arbeidswêreld}

Waar werkers deur regstellende aksie benadeel word, hef dit nie hulle arbeidsopdrag op nie. Die opdrag en roeping om deur werk in die eie lewensonderhoud te voorsien en die gemeenskap en God te dien, geld ook vir werkers wat deur regstellende aksie benadeel word. Gelowiges wat benadeel word, kan ten spyte van benadeling steeds hulle werk met vreugde doen, omdat hulle dit tot God se eer doen.

\section{Slot}

Regstellende aksie het sedert 1994 daarin geslaag om van die verkeerdhede op die arbeidsterrein reg te stel. Ongelukkig het saam met regstellende aksie ook nuwe arbeidspraktyke ontstaan wat teologies nie regverdigbaar is nie. Geregtigheid eis dat regstellende aksie binne 'n redelike tyd tot 'n einde moet kom.

\section{Geraadpleegde bronne}

AGRELL, G. 1976. Work, toil and sustenance. Verbum: Ohlssons.

ANON. 2001. Top blacks coining it. The Citizen: 7, 19 Mar.

ANON. 2003a. 2003 in Sake. Sake-Beeld: 15, 24 Des.

ANON. 2003b. Wit mans oorheers steeds die hoofbestuursposte in die land. Sake-Beeld: 2, 16 Jul.

ANON. 2006a. BEE deals total R55bn in 2005. http://www.fin24.co.za/articles/print_article.asp?articleid=1518-1786_1898012 Date of access: 14 Mar. 2006.

ANON. 2006b. Benadeeld. Beeld: 8, 17 Apr.

ANTONIDES, H. 1989. A Christian perspective on work and labour relations. Potchefstroom: Institute for Reformational Studies.

BIENERT, W. 1956. Die Arbeit nach der Lehre der Bibel: ein Beitrag zur evangelischen Sozialethik. Stuttgart: Evangelisches Verlagswerk.

BOOYENS, J. 1997. SA se mededingendheid bly in die slag. Rapport: 1, 27 Aug.

CAMERER, S. 2000. You still have a long way to go, sisters. The Citizen: 12, 25 May.

COETZEE, J.C. 1984. Paulus se eskatologiese prediking. (In Du Toit, A.B., red. Handleiding by die Nuwe Testament. Band 5. Pretoria: NG Kerkboekhandel. p. 332-364.)

DASNOIS, A. 2004a. Handful of new empowerment tycoons. Business Report: 12, 2 Feb 2004.

DASNOIS, A. 2004b. Nampak thinks out of the box on empowerment. Business Report: 2, 19 Jan 2004.

DAUTZENBERG, G. 1978. Arbeit und Eigentum. (In Hertz, A., Korff, W., Rendtorff, T. \& Ringeling, H., Hrsg. Handbuch der Christlichen Ethik Band 2. Basel: Freiburg. p. 343-362.) 
DE LANGE, J. 1999. Eskom verloor saak oor regstel-aksie. Sake-Beeld: 1, 13 Aug.

DE LANGE, J. 2003. 'n Gebrek aan sensitiwiteit vir menseregte? Sake-Beeld: 8, 27 Okt.

DUVENAGE, B. 1957. Beroepsarbeid in die lig van die Christelike etiek. Potchefstroom: PU vir CHO. (Th.D.-proefskrif.)

DUVENAGE, B. 1983. Roeping en wetenskap. Potchefstroom: EFJS.

DUVENHAGE, H. 2001. Openbare werke "aan spits" van swart bemagtiging. http://www.news24.co.za/contentDisplay/level4Article/0,1113,2_1049056, 00. html Datum van gebruik: 12 Nov. 2001.

ERASMUS, E. 2001. Salarisverskille tussen mans en vroue krimp, maar ... Beeld: 6, 3 Sept.

GARLINGTON, D.B. 1995. Righteousness. (In Atkinson, D.J. \& Field, D.H., eds. New dictionary of Christian ethics and pastoral theology. Leicester: InterVarsity. p. 743-745.)

GILIOMEE, H. 2003. The Afrikaner: biography of a people. Cape Town: Tafelberg.

GREMMELS, C. 1978. Fragen der Arbeit und der Arbeitswelt. (In Herz, A., Korff, W., Rendtorff, T. \& Ringeling, H., Hrsg. Handbuch der Christlichen Ethik. Band 2. Basel: Freiburg. p. 362-370.)

GUMEDE, W.M. \& QOZA, S. 2003. Viva black power! Sowetan: 1-2, 25 Mar.

HEYNS, J.A. 1986. Teologiese etiek. Deel 2/1. Pretoria: NG Kerkboekhandel.

HLANGANI, M. 2000. Affirmative action is the recipe for business growth. Sowetan: 16, 12 Dec.

HUMAN SCIENCES RESEARCH COUNCIL. 1999a. Top-class graduates not readily available. http:www.hsrc.ac.za/media/1999/8/19990816.html Date of access: 12 Jun. 2002.

HUMAN SCIENCES RESEARCH COUNCIL. 1999b. Women still lose out - but gap is closing. http:www.hsrc.ac.za/media/1999/10/19991025.html Date of access: 12 Jun. 2002.

JOHANNES PAULUS ॥ kyk JOHN PAUL II

JOHN PAUL II. 1981. Laborem Exercens. http://www.newadvent.org/docs/jp021e.htm Date of access: 16 Oct. 2003.

JOUBERT, J.-J. 1999. Swart bemagtiging "die rede vir handboek-probleme". Beeld: 1, 22 Feb.

KENNY, A. 2001. AA is a racist cancer in SA. The Citizen: 13, 18 Jul.

KOCH, K. 1984. צקד (In Jenni, E. \& Westermann, C., Hrsg. Theologisches Handwörterbuch zum Alten Testament. Bd. 2. München: Christliche Kaiser Verlag. p. 507-530.)

LE ROUX, M. 2003. Finansiële handves stel streng vereistes vir aankope. Sake-Beeld: 2, 20 Okt.

MABASA, T. 2002. Union to tackle affirmative action. The Citizen: 1-2, 10 Dec.

MASHALABA, S. 2002. Empowerment coup. Sowetan: 1-2, 13 Dec.

MBEKI, M. 2003. We need to develop real entrepeneurs. Saturday Star: 15, 5 July.

MDLADLANA, M. 2003. People with disabilities can work too. Sowetan: 15, 3 Dec.

MISBACH, W. 2002. Race and sex equity is on track. Sowetan: 4, 24 May.

MITTNER, M. 2001. Werkgewers werk saam oor regstellende aksie - minister. Sake-Beeld: 11, 24 Aug. 
NASIONALE DEPARTEMENT VAN OPENBARE WERKE

kyk SOUTH AFRICA. NATIONAL DEPARTOMET OF PUBLIC WORKS

NORVAL, E.J.G. 1966. Arbeid: prinsipiële ondersoek van arbeid met 'n kritiese toespitsing op enkele aktuele hoofprobleme van die arbeidsetiek. Potchefstroom: PU vir CHO. (Ph.D.- proefskrif.)

O'CONNOR, M. 2006. Bevoordeel swartes bo ander, beveel hof. Beeld: 7, 13 Apr.

OLIPHANT, L. 2003. Minister wants results on empowerment equity. Saturday Star: 5, 12 Apr.

OOSTHUIZEN, M. 2003. Regstellende aksie laat Arrive Alive misluk. Beeld: 1, 6 Jan.

PETERSEN, R. 1990. Die arbeider is sy loon werd. (In Van der Walt, B.J. Venster op die sakewêreld: perspektiewe op bedryfsetiek. Potchefstroom: Instituut vir Reformatoriese Studie. p. 179-188.)

POP, F.J. 1987. Bijbelse woorden en hun geheim. 's-Gravenhage: Boekencentrum.

RGN

kyk HUMAN SCIENCES RESEARCH COUNCIL

SATHEKGE, B. 2003. R10-bn to BEE over five years. The Citizen: 13, 29 Aug.

SEALE, T. 2001. Geslagspolisie ontplooi. Beeld: 9, 1 Mei.

SEFARA, M. 2003. Now for the real democracy: broad based empowerment. The Star: 9, 31 Mar.

SMITH, A. 2003. Call to blacklist white women from disadvantaged ranks. The Star: 3, 21 May.

SOUTH AFRICA. 1995. Labour relations Act, No. 66 of 1995. http://www.polity.org.za/govdocs/legislations/1995/act95-066.html Date of access: 10 Dec. 2001.

SOUTH AFRICA. 1996. Constitution of the Republic of South Africa Act, No. 108 of 1996. http://www.polity.org.za/govdocs/constitution/saconst.html Date of access: 13 Nov. 2001.

SOUTH AFRICA. 1997. Basic conditions of employment Act, No. 75 of 1997. http://www.polity.org.za/govdocs/legislation/1997/act75.pdf Date of access: 13 Aug. 2001.

SOUTH AFRICA. 1998a. Employment Equity Act, No. 55 of 1998. http://www.polity.org.za/govdocs/legislation/1998/act98-55.html Date of access: 10 Nov. 2001.

SOUTH AFRICA. 1998b. Skills Development Act, No. 97 of 1998. http://www.polity.org.za/govdocs/legislation/1998/act98-097.html Date of access: 2 Jun. 2002.

SOUTH AFRICA. 2000. Preferential Procurement Policy Framework Act, No. 5 of 2000. http://www.polity.org.za/govdocs/legislation/2000/act5.pdf Date of access: 10 Nov. 2001.

SOUTH AFRICA. 2003. Broad-based Black Economic Empowerment Act, No. 53 of 2003. http://www.polity.org.za/pdf/BroBasBlaEcoEmpA53.pdf Date of access: 27 Mar. 2006.

SOUTH AFRICA. NATIONAL DEPARTMENT OF PUBLIC WORKS. 2001. South African women in the construction industry. http://www.polity.org. za/govdocs/ pr/2001/pr0808a.html Date of access: 11 Nov. 2001.

STOKER, H.G. 1972. Arbeid: wysgerig benader. Bulletin van die SuidAfrikaanse Vereniging vir die bevordering van Christelike wetenskap, 31:43-60. 
STOKER, H.G. 1973. Arbeid - wysgerig benader. Bulletin van die SuidAfrikaanse Vereniging vir die bevordering van Christelike wetenskap, 36:527.

STUART, B. \& MALULEKE, J. 2003. White cops win jobs race case. The Citizen: 1-2, 8 Mar.

SWART, H. 1998. Regering wil wit groepe keer om swart frontfirmas te stig. Sake-Beeld: 1, 16 Sept.

TEMPELHOFF, E. 2003. Rand-Water moet opdok oor diskriminasie teen wit vrou. Beeld: 2, 2 Okt.

THEUNISSEN, G. 2005. Black execs worth 40\% more. http://www.fin24.co.za/ articles/default/display_article.asp?Nav=ns\&ArticleID=1518-25_1809917 Date of access: 29 Sep. 2005.

THOMASSON, E. 1999. Govt compels firms to promote blacks, women. http://www.news24.com/English/Business/Economy2/ENG_188259_8206 70_SEO.asp Date of access: 25 Nov. 1999.

UNITED NATIONS. 1979. Convention on the elimination of all forms of discrimination against women. http://www.un.org/womenwatch/daw/ cedaw/cedaw.htm Date of access: 17 Jun. 2002.

VAN DER MERWE, J.C. 1994. Regstellende aksie: prinsipiële riglyne. Potchefstroom: Instituut vir Reformatoriese Studie. (Studiestuk, 313.)

VAN HEERDEN, W. 1991. Profete en profytmakers: profetiese perspektiewe op rykdom en armoede. (In Bosman, H.L., Gous, J.P.G. \& Spangenberg, I.J.J. Purper en flenterlap. Pretoria: Van Schaik. p. 220-242.)

VAN ROOYEN, D. 1999. Dié rooster vir kontrakte help swart bemagtiging. Sake-Beeld: 11, 20 Okt.

VAN ROOYEN, L. 2004. It's tough getting work if you're a white male. Saturday star: 3, 10 Jan.

VAN WYK, J.A. 1988. 'n Christelike etiek van die arbeid. Pretoria: NG Kerkboekhandel.

VAN WYK, J.H. 1996. Arbeidsetiek: 'n teologies-etiese benadering. In die Skriflig, 30(2):155-183.

VELEMA, W.H. 1980. Bijbelse uitgangspunte van 'n Calvinistische beroepsethiek. Potchefstroom: Instituut vir die Bevordering van Calvinisme.

VOS, C.J.A. 1986. Etiese besinning oor die stem van die werker en die Woord van God. Theologia Viatorum, 14(1):1-12.

WEST, E. \& BLOOMBERG. 2003. Banks will sell equity stakes to compensate for apartheid. Business report: 1, 4 Sept.

ZIETSMAN, C. 2001. Skelms staan tou om swart gesigte in visbedryf te huur, sê hoë. http://www.news24.co.za/contentDisplay/level4Article/0,1113,2_ 1034100,00.html Datum van gebruik: 12 Nov. 2001.

\section{Kernbegrippe:}

arbeid

ekonomiese bemagtiging

regstellende aksie

vergoeding 


\section{Key concepts:}

affirmative action

economic empowerment

labour

renumeration 
